\title{
Gender Inequality in Education in Afghanistan: Access and Barriers
}

\author{
Zafar Shayan \\ Erciyes University, Kayseri, Turkey \\ Email: zza.shayan@gmail.com
}

Received 23 February 2015; accepted 22 April 2015; published 23 April 2015

Copyright (C) 2015 by author and Scientific Research Publishing Inc.

This work is licensed under the Creative Commons Attribution International License (CC BY). http://creativecommons.org/licenses/by/4.0/

(c) (i) Open Access

\begin{abstract}
As a traditional society, Afghanistan has always been a hotbed of gender inequality in different aspects. Especially, women/girls face various obstacles in education. Despite the efforts to improve the education sector in the last decade, the situation of female education still remains deplorable. There is still a long way to go in improving education, in particular female education. This article aims to examine the unequal access of females and males in primary, secondary and higher education, and presents the main obstacles that prevent women or girls from having access to education. The article is prepared by a desk study using a variety of presently available researches, papers and data related to education, women's rights and gender inequality from national and international organizations.
\end{abstract}

\section{Keywords}

\section{Gender Inequality, Education, Afghanistan, Women}

\section{Introduction}

Decades of conflict in Afghanistan, especially under the Taliban regime, destroyed almost all of the infrastructures including the educational system. The Taliban was against female education and banned female education in the country. This interruption caused irreparable damage with women being the most vulnerable of all those affected by this. According to the World Bank (2005), "In 2001 the overall adult literacy rate in Afghanistan was estimated at $36 \%$, while for adult women it was $21 \%$ ”. After the removal of the Taliban with the intervention of the United States and NATO, Afghanistan began to experience a new season. Over the last decade, Afghanistan has made improvements in some aspects, but still there are serious concerns.

In 2002, the international donors began collaborating with the government to improve the educational system. This resulted in some improvements compared with the previous decades. The schools and universities were 
reopened in most regions. However, the effective development of physical infrastructures and educational institutions is still facing various challenges. According to the Global Partnership for Education (2012), "The education sector of Afghanistan faces many challenges: low access to primary education, traditional obstacles to enrollment, in particular for girls, and low capacity within the Ministry of Education to deliver quality education service." In these circumstances, some people still oppose education, mostly in the southern parts of Afghanistan where the Taliban has strong influence among the people.

Today, there is a strong demand for and a positive attitude toward education among the majority of the public of Afghanistan. But tremendously high populations of young children, mostly girls, are still deprived of educational opportunities. The statistics provided by the Ministry of Education, Ministry of Higher Education and other researches show that the number of females attending schools and universities is lower than the number of males. The major hindrances responsible for the lack of access that females have to education include: religious and traditional beliefs, poverty, insecurity, marriage at early ages, unstable nature of the government etc. Some of these obstacles differ from region to region.

This article provides some statistics of the presence of females in formal education since 2002. It also briefly discusses the major obstacles that prevent women and girls from participating in the educational system. The last part of the article will present the conclusion and recommendation.

\section{Conceptual Framework}

Gender equality is defined in Oxford Dictionary as "the state in which access to rights or opportunities is unaffected by gender." Regarding this general definition, gender equality in education is when female and male students have the same right to and access to educational opportunities. There are four dimensions of gender equality in education, according to Subrahmanian (2003): "equality of access, equality in the learning process, equality in educational outcomes and equality of external results".

1) Equality of access means that male and female are provided equally with formal and non-formal educational opportunities. Both girls and boys can enroll in schools and universities and continue studying through higher levels.

2) Equality in the learning process refers to the equality and fairness in behavior, opportunities, participation, curriculum and teaching methods by the schools and universities towards their students.

3) Equality of educational outcomes means that girls and boys should be provided with equal success given equal effort. In other words, individual's successfulness and achievements, class examination and finally career should be unaffected by gender.

4) Equality of external results refers to the relative status of men and women in society after they complete their education. Women and men can equally participate in social, cultural, political and economic activities. And they can access to resources (as cited in USAID, 2008).

From the mentioned definition of each dimension of gender equality in education, we can conclude that enrollment, attendance, transition of male and female students between levels of education and equity of male and female teachers are the indicators of equality in access. The three other dimensions define the equality inside and after education like curriculum, behavior, outcome, examination, achievement and finally career. These dimensions are not going to be discussed in this study. This article examines the "equality of access", the first dimension of gender equality in education.

\section{Literature Review}

Gender inequality as a very prominent phenomenon exists in economic, cultural, social and political structures of Afghanistan. UNESCO says that "Afghanistan is one of the poorest and least educated countries in the world with large gender and geographical disparities in relation to access to education" (UNESCO Country Programming Document-UCPD, 2011). There are relevant studies carried out regarding the gender inequality in education by different research organizations. The literature mostly points to religious and traditional beliefs, poverty, insecurity, ethnic customs, geographical barriers and lack of quality service or corruption in the government as major obstacles for female education in Afghanistan.

The Department for International Development (DFID, 2005) indicates five main challenges for females when it comes to access to education; poverty, poor school environments, negative attitude toward women in society, insecurity and social exclusion (p. 6). These are presented as major challenges existing in different countries. 
The research carried out by UNICEF found that traditional and religious beliefs, stereotyped gender roles, the low status of women, early marriage, teaching programs and reproduction of gender roles in child care education and the contradictions of education with accepted roles in the society (as cited in İlhan Tunç, 2009).

Another study titled Afghanistan Education Sector Analysis carried out by Adam Smith International argues that, "lack of female teachers; limited number of girls' schools; cultural barriers; safety issues; security challenges; distance of travel; lack of relevance/practicality of the curricula; and lack of flexibility of the educational system” (Packer, Allsop, Dvorak, Stanley, \& Wirak, 2010).

UNESCO (2012) explains the major obstacles for females to progress in education as following:

- Socio-economic barriers: families with a good economic situation can provide their daughter/s with educational opportunities. Poor families are not able to support girls and sometimes they are obligated to work to support their families.

- Social and cultural expectations: values and traditional beliefs limit females. Parents don't allow their daughters to attend school nor universities.

- Rural dwelling: there is somehow deprivation in rural areas. Females can participate in primary school but they can't continue their education when they finish the primary level, because they need to move to the city in order to continue higher levels of education.

- Education policies and financing: one of the biggest problems for female education is that the government doesn't have such a policy to recognize the needs of girls/women and work. Sometimes the unequal distribution of governmental educational resources causes fewer enrollments of females in secondary education.

- Gender stereotyping in and through teaching practices and instructional materials: the differentiation of treatment and expectation of females and males within the educational system and after education.

- Violence: females are mostly faced with harassment and physical contact by male students and teachers. It causes parents to not want to allow their daughters to participate in education.

- "Lack of recognition and support for second chance literacy and non-formal education programs" as an alternative for females who are deprived of formal education (UNESCO, 2012, from Access to Equality).

A joint study carried out by a few international and local organizations in late 2010 on the obstacles against female education in Afghanistan, found that poverty, early marriage, insecurity, lack of family and community support, lack of female teachers, far distance of schools, very low quality of education, no girls' only school and violence are the main barriers which limit girls'/women's education participation (Jackson, 2011).

The aforementioned studies indicate various obstacles challenging female education such as; traditional and religious beliefs, political, economic, natural, lack of efficient management, harassment and insecurity. The studies carried out by DFID, UNISEF and UNISCO indicate general barriers that exist in most countries of the world. The research under the title of High Stakes-Girls' Education in Afghanistan taken place by 16 international and national organizations was the result of a survey in Afghanistan. In this research, the role of tradition and religion, different inter-ethnic values and insufficiency of educational management are ignored. The questions prepared for the participants don't reflect their own ideas. This article is not looking for the statistics of females suffering from poverty or other challenges. The purpose in this study is to analyze the obstacles identified by previous studies in the context of social realities of Afghanistan society.

\section{Methodology}

This article was based on a qualitative method using previous related studies carried out by prominent international and national organizations such as; UNESCO, USIAD, OXFAM, World Bank, Ministry of Education (MoE), Ministry of Higher Education (MoHE) of Afghanistan and some other studies carried out by researchers, and other journals and publications. In addition, the researcher used keywords on-line searches; this includes the concepts education, obstacles for female education and gender in/equality. The researcher attempted to select resources published in the most recent years. The selected resources are from well-known international and national organizations and researchers.

\section{Discussion}

Historically, women have been and remain to be in a critical condition in terms of education and social-political participation in the male-dominant society of Afghanistan. The low level of participation of women in education could be considered as a key challenge to the development of the country. The World Bank declares that, "before 1960 only men could receive a higher education". Gender inequality, particularly in education, reached its 
peak during the Taliban era. Jackson (2011) indicates that, "under the Taliban, the majority of girls' schools were closed and gross enrollment fell from $32 \%$ to just $6.4 \%$."

\subsection{Female Education since 2002}

A large number of international organizations started working towards contributing to the government of Afghanistan in order to rebuild the educational system since 2002. This resulted in some improvements in education. Despite the improvements the current situation of education is not as it was expected to be.

\subsubsection{General Education ${ }^{1}$}

The statistics show the very high differences of male-female ratio in each level of education. Female students are decreasing in higher levels of education. The Ministry of Education in its National Education Strategic Plan for Afghanistan -2010-2014 declares that, "of the 10,998 general education schools, 6071 are primary, 3061 are lower secondary and 1866 are upper secondary. Around 15\% are girls' school, 35\% are boys' schools, and 50\% are schools for both boys and girls who learn in different shifts. Of the total 412 rural and urban districts there are only 151 districts with at least one upper secondary girls' school; others do not have any upper secondary girls' schools" (MoE, 2010).

The number of girls' schools was still roughly about half the number of boys' schools in 1390 [2011]. In principle the mixed schools are open for both boys and girls usually in separate shifts (Lexow, 2012).

Regarding the reported numbers of enrollment (Grades 1-12) from 2002-2011 in general education by Lexow, the percentages of the female students in general education are $28 \%$ in $2002,34 \%$ in $2003,33 \%$ in 2004 , $34 \%$ in 2005, 35\% in 2006 and 2007, 36\% in 2008, 37\% in 2009, 38\% in 2010 and 39\% in 2011.

In 2013, 10.5 million students were studying at 16,600 schools which $38 \%$ of them were females. There were 210 thousand teachers with 32\% of them being women. In 2014, 1.7 million were enrolled which totally reaches to 11.5 million students of which $42 \%$ were females (MoE, Marifat Weekly, No. 170, April 2014).

\subsubsection{Teacher Training}

MoE (2010) says that, "four Teacher Training Colleges were functional in four out of 30 provinces with a total of 190 male students and 50 male lecturers [in 2001]. Female students did not have access to Teacher Training Colleges” (MoE, National Education Strategic Plan 2010-2014, 2010). The statistics released by the MoE shows that, in 2013, there were about 288 teacher training centers in the country. Around 68,000 students were studying of which 24\% were women (Rahman, Marifat Weekly-MeE, 2014). Currently, most of the teachers don't have a degree. Therefore, there is a need to improve the capacity and the performance of the Teacher Training Colleges.

\subsubsection{Higher Education}

Gender inequality in higher education is higher than in general education because females are mostly not provided with the opportunities to continue their studies in higher levels. According to Packer (2010), "by 2001 there were just 7800 students representing one of the lowest enrolment rates in the world.”

Enrolment of students in higher education from 2002-2012:

\begin{tabular}{cccc}
\hline \multirow{2}{*}{ Year } & \multicolumn{3}{c}{ Number of Students } \\
\cline { 2 - 4 } & Male & Female & Total \\
\hline 2002 & 27,000 & 4200 & 31,200 \\
2004 & 24,500 & 6200 & 30,700 \\
2006 & 30,600 & 8800 & 39,400 \\
2008 & 48,200 & 12,900 & 61,800 \\
2010 & 62,900 & 14,830 & 77,730 \\
2012 & 81,785 & 19,215 & 101,000 \\
\hline
\end{tabular}

(Source: Samady, 2013).

${ }^{1}$ According to Adam Smith International [ASI], the term general education refers to Grades 1 to 12 in state schools; covering primary, lower secondary and upper secondary levels of education. 
The number of students provided by Samady for 2012 differs from what is presented by the MoHE. But the percentage is the same. According to MeHE, about $(99,530)$ students were studying in the public universities across the country of which $19 \%$ were female (MoHE, n.d.) http://mohe.gov.af/?p=ehsaya. In 2014, there are about 15, 2354 students whom 20\% are female students. (Personal Communication, Nov 1, 2014). Regarding the statistics, women have a very low level of participation in higher education and a much lower level in the smaller institutions outside of the mains cities.

\subsection{The Main Obstacles for Female Education}

"Gender based stigma, discrimination, violence and stereotyping in education, as well as gender disparities in learning outcomes, are visible in all countries, regardless of the status of their economic or educational development” (UNESCO, UNESCO Priority Gender Equality Action Plan for 2014-2021, 2013). But gender equality is more tangible in Afghanistan. Women are in a deteriorating situation. According to World Bank (2005), "Afghanistan's education indicators are among the worst in the world that girls and rural populations are especially disadvantaged and have been so for decades". Main obstacles for female education in Afghanistan are discussed below.

\subsubsection{Traditional and Religious Barriers}

Tradition and religion, often inseparable, are the most important factors creating gender inequality in education. Inflexible traditional and religious beliefs have placed women in a poor status. Dominant religious persons/ groups think that their duties are to protect the traditions. In some parts of Afghanistan girls are only allowed to go to traditional Madaris, where they can learn only religious subjects. For instance, there is a traditional value among Pashtuns in the southeastern region of the country called "Pashtunwali". Jamal (2012) explains that Pashtunwali is a tribal code among Pashtuns of Afghanistan and Pakistan. It is not written but every Pashtun knows and practices that from childhood. He claims that Pashtunwali is a big obstacle for the education of females among them. There is a famous Pashtu proverb that says; "for a women either the house (kor) or the Grave (gor)". He adds that having female teachers is also a condition that needs to be met in order for the people to send their daughters to school according the Pashtunwali. Parents are not going to send their daughters to school if there are no female teachers (Jamal, 2012, Joint World Conference on Social Work and Social Development). The Taliban version of their attitude towards education is rooted in their tribal traditions. These restrictive codes are not maintained as strictly among those Pashtuns who live in the main cities. Contrariwise, female education is relatively in a good situation in other parts of the country like in the north and the west, and especially so in central parts of the country. According to National Geography Magazine, "Some 80 percent of eligible females attend school in the Hazara region—a stark contrast to 10 percent in five southern provinces" (Larson, 2008).

Afghanistan has one of the highest levels of illiteracy in the world. People are mostly following religious persons. Particularly in some rural areas females are not allowed by their families to go to school. "Many parents fear that their daughters will become alienated from traditional lifestyles and values, or that they will not make good wives and mothers, if they go to school” (UNESCO, 2012, from Access to Equality).

Early marriage is a social norm which decreases the participation of females in education. According to the Department for International Development, "more than 50 per cent of girls are married by age 18" in Afghanis$\tan$. As a result they are not allowed to attend school because of their domestic responsibilities and motherhood.

Attitudes towards education are not the same in all regions of the country. Various interpretations of their religion and inter-ethnic traditions impact the attitudes of the people towards education, especially female education. As a result, in some areas, women are considerably in a poor state; while in other areas women are in a relatively good state. This means that obstacles for female education have varying levels in different places and among different ethnic groups.

\subsubsection{Insecurity}

Insecurity is another factor which prevents girls from participating in education. The Ministry of Education estimates that, " 17 of Afghanistan's provinces offer secure access to education, while in the remaining 17 there are degrees of insecurity, although education provision is continually being negotiated with local communities" (MoE, National Education Interim Plan-2011-2013, 2011). The Taliban mostly attack or threaten girls' schools, 
teacher and students. "The UN reported more than 1000 attacks on education in 2009-2012, including schools being set on fire, suicide bombings and remotely detonated bombs, killings of staff, threats to staff and abductions” (Global Coalition to Protect Education from Attack-GCPEA, 2014).

GCPEA explains that, The Taliban tries to close girls' school by attacking, poisoning drinking water, releasing gas into the air and threatening the teachers, governmental employees and communities to close girls' schools by distributing "Night Letters", threatening letters. "Some letters warned that failure to comply with the demand would lead to retribution, such as acid or gas attacks" (GCPEA, 2014).

\subsubsection{Poverty}

According to the World Bank (2010), Afghanistan is one of the poorest countries in the world as the result of conflict and a low level of literacy. Poor families can't invest in their children's education, specially the families who have lost their men in the war. There are many families who obligate their daughters to work. Also, parents prefer to pay for their sons to attend schools. UNESCO says that, "Afghanistan is one of the poorest and least educated countries in the world with large gender and geographical disparities in relation to the access to education" (UN, 2013).

\subsubsection{Incompetent and Corrupt Education System}

Corruption is the biggest problem for the construction process. Afghanistan is ranked fourth on the Transparency International Corruption Index (Transparency International, 2014). Lack of clear and appropriate policies for female education and the failure to remove barriers are additional factors creating gender inequality in education. Hall says that, "planning and funding decisions made for personal and political reasons rather than based on objective technical criteria” (Hall, 2011). Favoritism in planning and unequal distribution of educational facilities keeps females out of school in many cases. The existence of unqualified personnel in each level causes a lack of innovation in the educational system. The Ministry of Education declares that:

"The government lacks the capacity to mainstream gender. Government agencies concerned with gender issues lack awareness of the importance of a gender-responsive approach towards policy making. They have insufficient institutional, management, and human resource capacities to mainstream gender into all aspects of their work. There is no accountability mechanism to evaluate performance on gender issues. Additionally, political will to accelerate reforms is often absent” (MoE, National Education Interim Plan2011-2013).

\subsubsection{Harassment}

Harassment at lower level schools and universities is another serious challenge for girls/women in education. Females are vulnerable to sexual violence by male student and teachers at school or on the way to school. Therefore, the fear of harassment keeps females illiterate in many cases. According to Human Development Center, "Harassment, kidnapping, elopement and cases of sexual assault appear to have a dramatic effect on school attendance. The vulnerability of girls to sexual attacks and abduction may explain the lower educational attainment of girls observed during violent conflict” (DFID Human Development Center, 2012).

\subsubsection{Lack of Female Teachers}

The lack of professional teachers is one of the greatest challenges for the development of education in Afghanistan. In this circumstance, a lack of female teachers is more tangible. Even girls' only schools face lack of female teachers. The government has to hire male teachers. Regarding their beliefs, parents disagree with male teachers in a girls' school. According to the MoE (2011), "Females constitute only 1 percent, 3 percent, and 4 percent of teachers in the provinces of Paktika, Khost, and Uruzgan” (MoE, National Educational Interim Plan; 2011-2013, 2011). Lack of female teachers can be cause and effect of low participation of girls in education.

\section{Conclusion and Recommendations}

There have been some improvements in the educational sector of Afghanistan in the last decade. The number of student's enrollment is increased since 2002. But the studies carried out on the situation of education in Afghanistan show the very poor state of female education. There is a lack of appropriate and efficient policies. The participation of women in education, especially in higher levels, has been considerably lower than men. Despite 
international cooperation and spending aids, the government has failed to take advantage of these opportunities. Still a high population of children, mostly females, is deprived of education. They face various challenges in education that can be summarized as: social-cultural norms, economic limitations, conflict and disturbance or physical and mental harms in educational environments.

Radical religious beliefs and absurd misogynistic traditions challenge female education. The majority of these obstacles are somehow related to people's beliefs. Parents are afraid of alienation of their daughters. In unsecured regions, the fear of Taliban's attack or kidnapping causes low participation of females at schools. Poverty is one of the other important factors; parents are not able to invest in their daughter's education. Meanwhile, lack of government's attention in establishing teacher training institutes in remote areas has resulted in a lack of female teachers. The low quality of educational services at schools and universities, in addition to other challenges, constrains female education in the country. Females are less likely to have access to schools in remote areas. In some areas, if girls are provided with opportunities to attend schools, they can't move to cities for higher education after graduation from lower level schools. They don't have the permission to live far from their families.

This study identifies that the most fundamental problem of women is the very patriarchal structure of the society. Inequalities originate from extreme religious beliefs and traditions. In traditional division of labor, a woman's role is within the household and is focused on serving a man. Women as half of the population and first educators of children can have important roles in development of a society. Hereupon, women's illiteracy can be considered as a big challenge for the progress of the country.

As it is argued before, the problem for female education is mostly the restrictive structure of the society. So, the social change desired doesn't take place in a short period of time. But still regarding the findings presented in this article the following recommendations can be offered:

- Develop local adoptable plans to explore educational opportunities for girls. In this case wide research is needed for the government to understand the problems in any part of the country.

- Increase qualified female teachers in the remote areas through establishing local teacher training centers.

- Motivate the female teachers through performance-based salary increment. Currently, those who have ability and higher degrees do not want to teach at schools because of the low wage unless they can't find highpaying jobs.

- Raise women's literacy level through establishment of literacy courses both in rural and urban areas. This could be effective in terms of changing the attitudes towards females' education.

- Strengthen communities' sense of ownership and responsibility through involvement in decision making processes.

- Strengthen government monitoring system on the projects implemented by the government itself, its contractors and NGOs. The budget should not be spent based on favoritism and biases. The government and international donors should focus on the areas with the greatest need.

\section{Acknowledgements}

The author would like to thank Dr. Koray Degirmenci for his advice during the preparation of this paper. Also thank you to Mr. Oluwole Adegbile for correcting the grammatical errors.

\section{References}

Department for International Development (DFID) (2005). Girls’ Education: Toward a Better Future for All. http://www2.ohchr.org/english/issues/development/docs/girlseducation.pdf

DFID Human Development Center (2012). Helpdesk Report: Violence and Sexual Abuse in Schools in Afghanistan and Pakistan.

http://www.heart-resources.org/wp-content/uploads/2012/11/Violence-and-Abuse-in-Schools-November-20121.pdf

Global Partnership for Education (2012). Afghanistan. http://www.globalpartnership.org/country/afghanistan

Hall, M. (2011). Corruption \& Afghanistan's Education Sector.

http://reliefweb.int/sites/reliefweb.int/files/resources/CFC_Afghanistan_Corruption_and_Education_Nov11.pdf

Global Coalition to Protect Education from Attack (2014). http://www.protectingeducation.org/country-profile/afghanistan

İlhan Tunç, A. (2009). Kız Çoculların Okula Gıtmeme Nedenleri-Van iliörneği.

http://efdergi.yyu.edu.tr/makaleler/cilt_VI/haziran/a_i_tunc.pdf 
Jackson, A. (2011). Girls’ Education in Afghanistan (A Joint Briefing Paper by 16 Organizations).

Jamal, A. (2012). Engaging Men in Gender Justice—2012 Joint World Conference on Social Work and Social Development. http://www.youtube.com/watch?v=CILzDOUa9jY

Larson, M. (2008). Hazara People—National Geographic Magazine. http://ngm.nationalgeographic.com/geopedia/Hazara_People

Lexow, J. (2012). Afghanistan Education Sector Gender Equality-Situational Analysis. http://ncg.no/index.asp?id=35093

MoE (2010). National Education Strategic Plan for Afghanistan-2010-2014.

MoE (2011). National Educational Interim Plan; 2011-2013.

MoHE (n.d.). Statistics. http://mohe.gov.af/?p=ehsaya

Packer, Allsop, Dvorak, Stanley, \& Wirak (2010). Afghanistan Education Analysis. Adam Smith International. http://www.giz.de/en/downloads/en-adam-smith-international-draft-nesp-assessment-2011.pdf

Rahman, G. (2014). A Brief Report on Achievements the Ministry of Education in 1392 [2013]. Marif Weekly, No. 170. http://moe.gov.af/Content/files/170.pdf

Samady, S. (2013). Changing Profile of Education in Afghanistan. http://eslus.com/articles/Ed-Afghanistan.pdf

Subrahmanian, R. (2003). Gender Equality in Education: Definition and Measurements.

Transparency International Index (2014). http://www.transparency.org/

UN (2013). Convention on the Elimination of All Forms of Discrimination against Women. http://www.ohchr.org/Documents/ProfessionalInterest/cedaw.pdf

UNESCO (2012). From Access to Equality_Empowering Girls and Women through Literacy and Secondary Education.

UNESCO (2011). UNESCO Country Programming Document (UCPD)—Afghanistan, 2010-2011. http://unesdoc.unesco.org/images/0018/001875/187584e.pdf

UNESCO (2013). UNESCO Priority Gender Equality Action Plan for 2014-2021. http://www.unesco.org/new/fileadmin/MULTIMEDIA/HQ/BSP/GENDER/GEAPENGLISHFINAL.pdf

USAID (2008). Gender Equality Frame Work.

World Bank (2005). Afghanistan National Reconstruction and Poverty Reduction-The Role of Women in Afghanistan Future. World Bank Electronic Library. 